\title{
THE RELATIONSHIP BETWEEN CRITICAL THINKING, ITS SUBSCALES AND ACADEMIC ACHIEVEMENT OF ENGLISH LANGUAGE COURSE: THE PREDICTABILITY OF EDUCATIONAL SUCCESS BASED ON CRITICAL THINKING
}

\section{ABSTRACT}

Among the factors influencing students' educational performance of English language course, critical thinking is thought to be of crucial importance. Thus, the present study set out to explore the relationship between critical thinking, its subscales and English language achievement. Also, the predictability of English language proficiency based on critical thinking was investigated. The statistical population included all eleventh grade female students in district one of Zanjan city in the academic year of 2018-2019 with1400 people. The statistical sample was 300 people based on Cochran's formula. A multi-stage random sampling method was used to select the participants. The California Critical Thinking Skills Test, Form B was used to assess students' critical thinking ability. The participants' scores of English language course at the end of the first semester were considered as a criterion for their English language proficiency. The results of the correlation analyses revealed that critical thinking and its subscales correlated significantly with academic achievement $(p=0.0)$. Also, based on regression tests, it was revealed that English language proficiency is predictable based on critical thinking. The findings of this study would be beneficial for students, teachers, schools and educational officials.

Keywords: Academic achievement, Critical thinking, Predictability

DOI: $10.31805 /$ acjes.445545

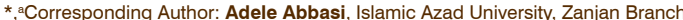
Department of English Language Education, Zanjan/Iran, E-Posta: ad.abbasi59@gmail.com (D) https://orcid.org/0000-0003-0283-6939

'Islamic Azad University, Zanjan Branch, Department of English Language Education, Zanjan//ran Posta: cyrosizadpanah@yahoo.com -Phttps://orcid.org/0003-2938-0767 


\section{INGILIZCE DERSINDE ELEŞTIREL DÜŞÜNME VE ALT FAKTÖRLERININ BAŞARI ILE ILIŞKISI: ELEŞTIREL DÜŞÜNMENIN EĞiTIM BAŞARISI ÜZERINDEKI ÖNGÖRÜLEBILIRLiĞi}

Adele Abbasia, ${ }^{i}$, Siros Izadpanah ${ }^{b}$

\section{ÖZET}

Öğrencilerin İngilizce eğitim performansını etkileyen faktörler arasında, eleştirel düşünmenin çok önemli olduğu düşünülmektedir. Bu nedenle, bu çalışma eleştirel düşünme, alt ölçekleri ve İngilizce dilindeki başarı arasındaki ilişkiyi araştırmaya yöneliktir. Araştırmada ayrıca eleştirel düşünmeye dayalı Ingilizce dil yeterliliğinin öngörülebilirliği araştırımıştır. Araştırmanın evrenini, 2018-2019 öğretim yılında Zanjan şehrinde öğrenim gören ve tamamı kadın olan 1400 on birinci öğrencisi oluşturmaktadır. Araştırmanın örneklemine ise Cochran'ın formülüne göre 300 kişi dahil edilmiştir. Katılımcıların belirlenmesinde çok aşamalı rasgele örnekleme yöntemi kullanıldı. Öğrencilerin eleştirel düşünme yeteneğini değerlendirmek için California Eleştirel Düşünme Becerileri Testinin B formu kullanılmıştır. Katıımcıların ilk dönem sonunda aldıkları İngilizce dil kursu puanları İngilizce dil yeterlilikleri için bir kriter olarak değerlendirilmiştir. Araştırmanın sonuçları eleştirel düşünme ve alt faktörlerinin akademik başarı ile anlamlı bir kolerasyon ortaya koyduğunu göstermektedir. Ayrıca regresyon testlerine dayanarak, eleştirel düşünceye dayalı olarak İngilizce dil yeterliliğinin öngörülebilir olduğu ortaya çıkmıştır. Bu açıdan bu çalışmanın bulgularının, öğrenciler, öğretmenler, okullar ve eğitim yetkilileri için yararlı olacağı düşünülmektedir.

Anahtar Kelimeler: Akademik başarı, Eleştirel düşünme, Öngörülebilirlik

MAKALE HAKKINDA

Gönderim Tarihi: 25 July 2018

Revize Tarihi: 26 October 2018

Kabul Tarihi: $\mathbf{3 0}$ October 2018

DOI: $10.31805 /$ acjes.445545

*, aSorumlu Yazar: Adele Abbasi, Islamic Azad Üniversitesi, Zanjan Branch, İngiliz

Dili Eğitimi Bölümü, Zanjan/iran,

Dhttps://orcid.org/0000-0003-0283-6939

Islamic Azad Üniversitesi, Zanjan Branch, İngiliz Dili Eğitimi Bölümü, Zanjan/iran,

E-Posta: cyrosizadpanah@yahoo.com

Dhttps://orcid.org/0003-2938-0767

E-ISSN: 2602-3342

Copyright $\odot$ ACJES 
Education specialists have always paid special attention to academic progress and to the factors Affecting it. The most significant predictor of the success of students is their ability, however it can not predict academic achievement alone. Therefore, researchers have tried to measure the role of non-educational factors on academic progress and one of these factors is critical thinking (Fong, Kim, Davis, Hoang,\& Kim, 2017; Sepahi Khazaei, Khoshay, Iranfar,\& Timare, 2016; Vierra, 2014). The world today is the era of information explosion and humans need to seek a way to screen information, and critical thinking can make it possible for a person to search for truth in the confluence of events and attain his goal of achieving complete understanding because critical thinking creates the mental and physical power for a person to prepare himself for the challenges of rapidly changing world (Trenholm, 2017). Skills of critical thinking are of high significance, since by using those abilities students can deal with social, scientific, and functional problems. These students have problem-solving abilities. The skills required for solving problems critically are reasoning, estimating, solving problems, making decisions, and finally analyzing the results and this process can be done individually or collaboratively (Magrabi, Pasha,\& Pasha, 2018). Educational specialists believe that being critical is significant in learning and state that being able to identify, creating and assessing debates, examining carefully, integrating, and evaluating materials are the basis of educational achievement in higher education (Li, 2016).

So far, various studies have been conducted to investigate the relationship between critical thinking and academic achievement. Some of them have found a significant relationship between them (Fong et al., 2017; Ghanizadeh, 2017; Ross, Leoffler, Schipper, Vandermeer, \& Allan, 2013; Vierra, 2014). However, some of the researchers did not find any correlation between critical thinking and students' educational achievement (Bakhshi \& Ahanchian, 2013; Doleck, Bazalais, Lemay, Saxena, \& Basnet, 2017; Shirrel, 2008).

Although most research in this regard has explored the relationship between critical thinking and general academic achievement, few studies, if any, have explored the relationship between critical thinking and academic success of English language course. Moreover, to the best of the researcher, few studies, if any, have investigated the relationship between subscales of critical thinking with academic performance. Furthermore, previous studies have achieved contradictory results.

On the other hand, in the contemporary world which is rapidly changing, the significance of English language and the necessity to learn it, is felt increasingly. Mastery of English language and the ability to speak it fluently is a benefit in people's lives ( Pramila, Bahadur, \& Bahadur, 2018). English language is the language of business communications (Evans, 2013). Moreover, it Is the language of science and scientific works. Researches, and publications are in English. Besides, it is the language which is used in formal education all over the world. Therefore, it is necessary to excel it in the scientific era (Pramila et al., 2018).

Consequently, due to the significance of enhancing English language proficiency, and the importance of critical thinking in education, this study investigated the relationship between critical thinking and its subscales with academic achievement of English language course. Also, the predictability of students' English language proficiency based on critical thinking was investigated. Therefore, the following research questions were formed:

1- Is there any relationship between critical thinking and its subscales with eleventh grade female students' academic achievement of English language course?

2- Is eleventh grade female students' academic achievement of English language course predictable based on critical thinking?

\section{Review of Literature}

In today's advanced world, one of the criterion for individual's success is academic achievement. 
Students' academic progress represents the extent to which educational goals are achieved. Teachers, students, parents, and theorists have concerned about academic achievement. In case of educational success, the students will be accepted by others and in the case of academic failure, they will doubt their abilities. Considering that one of the criterion for the effectiveness of the educational system is the rate of progress, it is important to discover and study the variables affecting academic achievement. Educational achievement is the result of the instruction which the teacher conveys to students. From the factors influencing academic achievement, critical thinking is thought to be influential. According to Kelly and Lincona (2018), education is based on thought, and critical thinking requires students to think carefully while learning, and this is done by the use of some abilities, manners and characteristics like rationality and intuition.

\section{Academic Achievement}

According to Shoval, Sharir, Arnon, and Tenenbaum (2018), academic achievement is the extent to which the learner is benefitting from training in a given field of knowledge or educational success is displayed by the extent to which the learners benefit from the ability and instruction which have been conveyed to them. It is the result of learning which is assessed by classroom grades and evaluations, as well as external achievement tests (Gajda, Karwowsky, \& Beghetto, 2016). Students' academic performance whether measured quantitatively and through grades or qualitatively, is the main concern of educational systems, governments, policy-makers, principals parents and teachers (Kahu \& Nelson, 2017). Most of the time, students' grade point average (GPA) is used to indicate their academic achievement. Gelardi and Emby (2005), Hong (2002), Hirish and Peterson (2008) reported significant relationship between cumulative grade point average and students' educational performance.

\section{Iranian Studies in Academic Achievement}

Due to the importance of academic achievement, a number of research studies have dealt with it. In their study, Vizeshfar and Torabizadeh (2018) investigated the effect of education based on dominant learning styles on the educational performance of nursing students in Shiraz. The participants of the study were 40 nursing students. The Kolb's learning style questionnaire was used to collect data. In Iran, nursing students should take a course entitled "The Principles of Patient Education" and the researchers' aim was to maximize the students' learning in this course. A pretest was taken about the topics of the course, then they answered the Kolb's questionnaire. According to the results of the questionnaire, the participants preferred learning style was the divergent style, so, the students were taught through group discussion and next, a posttest was given to them. The findings of the study revealed that education which is on the basis of learning styles has a positive effect on academic performance.

Hakimi, Hejazi, and Gholamali Lavasani (2015) conducted a study to measure the relationship between cognitive styles and personality traits with academic performance. Participants of the study were 285 students (191 females and 94 males) at college of Economics and college of Management in Tehran University. In order to assess cognitive styles, the Group Embedded Figure Test, and in order to evaluate students' personality characteristics the Neo-Five Factor Inventory Questionnaire were used. Also, to assess students' academic achievement, the college Grade Point Average (GPA) of the participants was used. The findings of the study showed that there is a significant positive relationship between cognitive styles and personality traits with educational performance. Moreover, the results revealed that there is no difference between cognitive styles, personality features and academic performance in gender.

In 2015, Zare and Rastegar explored the role of intelligence beliefs, achievement goals, and academic emotions on educational achievement. Participants of the study were 231 post-graduate students in Fars Payame Noor University which were selected randomly. The students completed Intelligence Beliefs questionnaire, Achievement Goals questionnaire, and Academic Emotions questionnaires. To assess students' academic achievement, the students' final grade point average was used. The findings of the study revealed that incremental intelligence beliefs are related to academic performance. Moreover, the entity intelligence beliefs are not related to academic achievement.

Although these researchers studied the relationship between different factors such as self-efficacy, learning strategies, motivation, technology and so on with academic achievement, they had 
an emphasis on general academic performance. Therefore, the researcher aimed at doing this research considering English language proficiency.

\section{International Studies in Academic Achievement}

Topcu and Leana-Tascilar (2018) explored the relationship between self-esteem and motivational components with educational performance of Turkish gifted students. Sample of this research were 184 students, 108 males and 76 females (grade four: 61 students, grade five: 43 students, grade six: 34 students, grade seven: 32 students, and grade eight: 14 students). From these students 84 students attended Istanbul Art and Science Center, and 100 of them attended a Public Special Education School for talented students. In order to assess self-esteem, the Coopersmith self-esteem inventory was used and for examining motivational components, the Scale of Intrinsic Versus Extrinsic Motivational Orientation was applied. The results of theresearch proved that there is a significant relationship between motivation, self-esteem, and academic performance.

Seah (2018) explored how immigrant teachers influence the educational performance of secondary school students in the United States. The total number of the participants were 44077 students from which 10775 students were in the Science course,11285 students were in the mathematics course, 10561 students were in the Social Studies course, and 11456 students were in the English course. Students' academic success in the Science, Social Studies, Mathematics, and English course were received by the participants in standardized tests. In order to assess the effect of immigrant instructor, the achievement of the students with immigrant teachers were compared to the achievement of students with an immigrant instructor in one subject. The findings of the study revealed that immigrant educators do not have a negative influence on the educational performance of native students.

In an investigation, Zhang and Lynch (2018) explored the relationship between primary five and six students' understandings of parental encouragement and their educational success in Mandarin learning. The study was conducted at an international school in Bangkok. The participants were 103 students who were learning Mandarin in primary 5 to 6 at school. To assess parental encouragement, Parental Encouragement Questionnaire was applied. To examine students' academic achievement in learning Mandarin, the participants' Mandarin academic performance scores at the end of the second term was used. The results of the research revealed that there is a positive relationship between primary five and six students' understandings of parental encouragement and their academic performance.

However, one question that needs to be asked in some of these studies is whether they have been conducted on females or males and the exact number of participants has not been determined by gender. Also, in some of them the way of assessing academic achievement is no clear.

\section{Critical Thinking}

The origins of critical thinking goes back to the works of Aristotle, Socrates, and Plato. Socrates concentrated on introspection and argued for thought, investigation, and willingness to criticism which is required for human achievement. Aristotle and Plato focused onusing reason and inquiry to judge reasonably which results in personal freedom. They emphasized on the significance of logic and critical thinking in achieving freedom. John Dewey, the American philosopher of education, focused on the crucial role of critical thinking at education as well (Vierra, 2014). In this regard, Buskist and Irons (2008) say "if there is one thing that all college and university teachers want their students to learn, it is to think critically" (p.49, cited in Jahn \& Kenner, 2018). It is necessary for people to enhance and use critical thinking skills because it is crucial in the 21st century (Kharbach, 2012, cited in Fuad, Zubaidah, Mohanal, \& Suarsini, 2017). Science and technology have been advanced in this century and it is necessary for the students to process the thinking skills to be able to make decisions in order to attain new knowledge rapidly (Lau, 2011).

Critical thinking is needed to promote thinking skills of the students (Hashemi, 2011). Most of the educators believe that critical thinking is a primary goal of education (Thadphoothon, 2005) which was displayed through different types of conscious effect on thinking quality, autonomy in making decision, and responsibility of action (Gajcov, Stojanovic, \& Rajic, 2014).

A wide range of definitions have been proposed for critical thinking. Critical thinking includes various skills involving the evaluation of the source of knowledge, assessing the validity of the informati- 
on, assessing its reliability, and finding suitable descriptions for particular tasks and conditions (Hong \& Choi, 2015). Voskoglou and Buckley (2012) believe that critical thinking is the capability or skill by which a person surpasses him/herself willingly in order to arrive at outcomes that can be established by the use of sound data. Stein, Haynes, Redding, Ennis, and Cecil (2007) consider critical thinking as rational thinking which is involved in making decision, accepting beliefs or doing things and include activities such as making hypothesis, various ways of considering issues and problems and possible solutions, and designing different plans for reviewing different affairs. In Acharya (2017)'s point of view critical thinking is the ability to think in unusual way, to see the situations from different perspectives, and to think beyond the restrictions which will lead to creative solutions. Guven and Kurum (2007) state that good learners should know the way of learning and thinking. Efficient earning is associated with learners' consciousness about how to learn and think and this means critical thinking. Willingham (2008, p. 8) defined critical thinking as "seeing both sides of an issue, being open to new evidence that disconfirms your ideas, reasoning dispassionately, and demanding that claims be backed by evidence". It is a meta-cognitive system which produces rational outcome to a discussion and solves problems using thoughtful assessment (Dwyer, Hogan,\& Stewart, 2014).

Due to the significance of critical thinking, especially in the realm of education, numerous studies have been conducted to evaluate its relationship with different matters and particularly with educational performance.

\section{Iranian Studies in Critical Thinking}

Ghanizadeh (2017) conducted a research entitled "the interplay between reflective thinking, critical thinking, self-monitoring, and academic achievement in higher education". The sample of the study included 196 Iranian university students (75 males \& 112 females). In order to assess reflective thinking, students answered the Reflective Thinking Questionnaire, and in order to evaluate critical thinking, Watson-Glaser Critical Thinking Appraisal was completed by the participants. Self-monitoring was assessed by using the Self-Regulation Trait Questionnaire. The findings of the study revealed that critical thinking and reflective thinking are related to academic achievement.

In their investigation, Sepahi, Khazaei, Khoshay, Iranfar, and Timare (2016) examined the relationship between critical thinking disposition and academic achievement of preclinical and clinical medical students. Participants were 259 students at Medical Sciences University of Kermanshah. For measuring critical thinking, the Standard Critical Thinking Disposition Inventory Test was used. The students' grade point average of the previous terms was used as a criteria for academic achievement. The results showed that critical thinking has a significant relationship with academic performance in the preclinical stage. However, in the clinical stage this relationship was not significant.

In 2014, Ashoori investigated the relationship between academic achievement and self efficacy, critical thinking, thinking styles and emotional intelligence in nursing students. Participants were 140 nursing students (44 males \& 96 females) in Islamic Azad University of Varamin-Pishva which were chosen through stratified random sampling. To assess self-efficacy, Sherer's General Self-Efficacy Scale was used. To evaluate critical thinking, Rickett's CriticalThinking Disposition Questionnaire was applied. To measure thinking styles, Sternberg's Thinking Styles Inventory was used. In order to assess emotional intelligence, the students completed Bar-On Emotional Intelligence Questionnaire. The findings of the study revealed that the variables of the research had a positive relationship with academic achievement.

However, various studies investigated the relationship between different factors, critical thinking, and academic success, most of them just focused on general academic achievement. Also, to the best of the researcher, none of them has considered the relationship between the components of critical thinking with educational performance.

\section{International Studies in Critical Thinking}

In an investigation in 2017, Doleck, Bazalais, Lemay, Saxena, and Basnet studied the relationship between computational thinking skills (algorithmic thinking, cooperativity, creativity, critical thinking, and problem solving) and educational performance. Participants were 104 students (54 females \& 50 males) and their mean age was 17.9 years. They completed questionnaire which had two sections: "introduction" section which included demographic and academic information and "computa- 
tional thinking" section which had 29 items and was divided into five sections: algorithmic thinking, cooperativity, creativity, critical thinking, and problem-solving. Items were scored on a five point Likert-scale ranging from 1 to5(never to always). Academic achievement was assessed by the use of the students' grade point average. The results of the research showed no association between computational thinking skills and academic success. The only correlation was between cooperativity and academic performance.

Fuad, Zubaidah, Mahanal and Suarsini (2017) conducted a research entitled "improving junior high schools critical thinking based on three different models of learning". Participants of the study were 96 seventh grade students of junior high schools in Indonesia. The data from critical thinking skills were gained from scoring rubric with a scale of 0-5 and then were analyzed by the use of ANCOVA. The study was quasi-experimental research with pretest, posttest and non-equivalent control group design. Learning models were differentiated science inquiry combined with mind map, differentiated science inquiry model, and conventional model. The result showed that the students who were given differentiated inquiry model combined with mind map gained the highest skills in critical thinking.

To assess the relationship between critical thinking skills and academic achievement, Vierra (2014) conducted a study and discovered the degree to which demographic features controlled the relationship. Sample of the study consisted of 297eighth grade students at Shanghai American school. To investigate critical thinking skills, the California Critical Thinking Skills Test Middle School Series was used. Academic achievement was measured by using teacher assigned grades and the Measures of Academic Progress Test. Demographic factors were self-reported by the students. The findings of the study proved that critical thinking skills were strongly related to academic performance and demographic factors did not moderate the relationship.

Although some scholars studied the relationship between critical thinking and educational success, the way of selecting participants has not been mentioned in some of them. Also, no specific tests have been used to assess their educational progress.

\section{Method}

\section{Participants}

The statistical population of this study included all the eleventh grade female students of district one of zanjan city (1400 students), ranging in age from 15 to 16 who were studying at district one schools in the academic year of 2018-2019. The sample size was about 300 people based on Cochran's formula. To choose the sample in question, the multi-stage random sampling method was used in a way that from the 16 girl schools, 6 schools were selected and from each school, 2 eleventh grade classes were chosen randomly. Finally, 300 students were invited to collaborate in this research.

\section{Instruments}

In this study, the California Critical Thinking Skills Test (CCTST) Form B, was used to measure students' criticalthinking skills. Facione and Facione (1993), have designed this test on the basis of Delphi agreement and based on the views of 46 experts and theorists in the field of critical thinking in different disciplines. This conceptualization of critical thinking has been approved by the National center for Education, Learning, and Higher Assessment at Pensylvania State University of America. This test is used for group assessment, program assessment and also acceptance of people in different affairs. In this test, a general score for critical thinking is got for each subject. The content of the test has not been taken from the contents of a particular discipline. Also, technical and specialized words has not been used in this test (Facione, 2000). This test is in five areas of critical thinking including evaluation, inference, analysis, deductive reasoning, and inductive reasoning. CCTST has 34 multiple-choice questions and each question is scored one for each correct answer and zero for each wrong answer. Therefore, the lowest total score is 0 and the highest total score is 34 The time limit for completing this questionnaire is about 45 minutes (Facione \& Facione, 1997).

\section{Reliability of CCTST}

In 2009, The California Critical Thinking Skills Test was translated to the Persian language by Akhoundzadeh, AhmariTehran, Salehi, and Abedini and they reported that this test's reliability is 
0.62 (as cited in Azizi-Fini, Hajibagheri, Adib-Hajibagheri, 2015). Also, Khalili and Hossein Zadeh (2003) reported the same result which was obtained with the internal consistency method and with KR-20. Facione and Facione (1993) claimed that a KR-20 range of $0.65-0.75$ is good for this questionnaire. In this study, in order to evaluate the reliability of the CCTST, Kuder Richardson method was used. The following table shows the results:

Table 1. The Result of the Kuder-Richardson Test

\begin{tabular}{ccccccc}
\hline & $\begin{array}{c}\text { Inductive } \\
\text { Reasoning }\end{array}$ & $\begin{array}{c}\text { Deductive } \\
\text { Reasoning }\end{array}$ & Analysis & Inference & Evaluation & $\begin{array}{c}\text { Critical } \\
\text { Thinking }\end{array}$ \\
\hline Results & 0.720 & 0.741 & 0.725 & 0.702 & 0.731 & 0.748 \\
\hline
\end{tabular}

As seen in Table1, critical thinking variable and all its subscales are higher than 0.7 . Therefore, the CCTST has an appropriate reliability.

\section{Validity of CCTST}

The construct validity of the Persian version of the CCTST which was examined with factor analysis revealed that there is a correlation between test structure and theory of the test. Also, all of the subscales (analysis, evaluation, inference, inductive reasoning, and deductive reasoning) investigate one single construct which is critical thinking. Internal consistency method revealed that all of these five factors have positive correlation with total test score Khalili \& Hossein Zadeh, 2003). The content validity of the CCTST is high and is able to distinguish between critical thinking skills of nursing and philosophy students (Aaiai-Fini et al., 2015). In the present study, to evaluate content validity, the CVR (Content Validity Ratio) and the CVI (Content Validity Index) methods were used. The following table shows the results:

Table 2. The Result of the Validity Tests of Critical Thinking Variable and its Subscales

\begin{tabular}{ccccc}
\hline Variables & $\mathrm{n}_{\mathrm{E} 1}$ & $\mathrm{n}_{\mathrm{E}}$ & CVI & CVR \\
\hline Inductive Reasoning & 18 & 15 & 0.90 & 0.50 \\
\hline Deductive Reasoning & 18 & 18 & 0.90 & 0.80 \\
\hline Analysis & 17 & 16 & 0.85 & 0.60 \\
\hline Inference & 16 & 16 & 0.80 & 0.60 \\
\hline Evaluation & 19 & 19 & 0.95 & 0.90 \\
\hline Critical Thinking & 17 & 18 & 0.80 & 0.80 \\
\hline
\end{tabular}

Note: The index of CVR for 20 people should be more than 0.42 and of CVI should be more than 0.79 .

As seen in Table 2, the CCTST has a desirable validity.

\section{Procedure of The Data Collection}

Before distributing the questionnaires among participants, backward and forward translation was done. The CCTS questionnaire was translated into Persian language. First, the English version was given to two expert translators to translate it into Persian language, and then, two other expert translators were asked to translate the Persian version of the questionnaire into English language and this version was compared by the original English questionnaire by the two experts in English language and finally one of the Persian versions of the questionnaire which was the most appropriate translated version was selected as the questionnaire of the current research.

After getting permission from the Educational Department for selected schools, questionnaires were passed to selected students. Since responding to the questionnaires was time-consuming, they were delivered to the students and explanations were given so that they respond them at home (California Critical Thinking Skills Test required at least 45 minutes).

To measure academic achievement of the participants, the score that each of the students gained from the assessment of English language course at the end of the first semester was used. 


\section{Data Analysis Methods}

Quantitative data was analyzed using SPSS, version 22. In order to analyze the obtained data, descriptive and inferential statistics were used. Descriptive statistics include descriptive methods to explain central index tables and dispersion of all variables that were used to classify, summarize, and describe the obtained data. In the inferential statistics, correlation and regression tests were used to test the hypotheses and answer the research questions. Also, in order to generalize the results and test the hypotheses, the obtained coefficients were tested at the significance level of alpha 0.5 .

\section{Design of the Study}

In order to investigate the research questions, the researcher employed an ex-post facto design since there was no treatment at all. There was one independent variable which was critical thinking and one dependent variable which was academic achievement of English language course. Critical thinking, was operationalized via the California Critical Thinking Skills Test, Form B. In the first question, the relationship between critical thinking and academic success of students' English language course was accounted for. In the second question, the predictability of students' academic achievement in English language course based on their critical thinking was taken into consideration.

\section{Findings}

\section{Descriptive Analysis}

To answer the research question, the descriptive analysis of critical thinking, its subscales and academic success was performed.The central indices and the distribution of the answers to the questions related to critical thinking, its subscales, and academic achievement have been shown in the following tables:

Table 3. Frequency Distribution and Descriptive Indices of Responses Related to Academic Achievement Variable

\begin{tabular}{cccccc}
\hline & Mean & Median & Std. Deviation & Skewness & Kurtosis \\
\hline $\begin{array}{c}\text { Academic } \\
\text { Achievement }\end{array}$ & 15.82 & 16.00 & 3.14 & -0.68 & -0.43 \\
\hline
\end{tabular}

As seen in Table 3, the mean of academic achievement is 15.82. Due to the values of Skewness and Kurtosis, since these values are between -1 and +1 , the distribution of the variables is close to normal distribution.

Table 4. Frequency Distribution and Descriptive Indices of Responses Related to the Critical Thinking Variable and its Subscales

\begin{tabular}{cccccc}
\hline & Mean & Median & Std. Deviation & Skewness & Kurtosis \\
\hline Inductive Reasoning & 11.29 & 12.00 & 3.13 & -0.109 & -0.347 \\
\hline Deductive Reasoning & 10.32 & 11.00 & 2.39 & -0.981 & 0.169 \\
\hline Analysis & 6.44 & 7.00 & 1.54 & -0.494 & -0.662 \\
\hline Inference & 7.71 & 8.00 & 2.37 & -0.638 & -0.338 \\
\hline Evaluation & 9.38 & 10.00 & 2.86 & -0.524 & -0.672 \\
\hline Critical Thinking & 27.35 & 28.00 & 4.68 & -0.717 & -0.241 \\
\hline
\end{tabular}

As seen in Table 4, the mean of the subscales of inductive reasoning, deductive reasoning, 
analysis, inference, and evaluation were $11.29,10.32,6.44,7.71,9.38$ respectively. Also, the mean of total critical thinking variable was 27.35. Due to the values of Skewness and Kurtosis, since these values were between -1 to +1 , the distribution of the variables was close to normal distribution.

\section{Inferential Analysis}

In the inferential analysis section, first of all, the normality of the variables was investigated using Kolmogorov-Smirnov test. Then, the relationship between dependent and independent variables was checked by the use of Pearson correlation test and regression test. Finally, research hypotheses were examined.

\section{Checking the Normality of The Variables}

To check the normality of research variables Kolmogorov-Smirnov test was used:

Table 5. The Output of Kolmogorov-Smirnov Test to Examine the Normality of the Critical Thinking Variable

\begin{tabular}{ccccccc}
\hline & $\begin{array}{c}\text { Inductive } \\
\text { Reasoning }\end{array}$ & $\begin{array}{c}\text { Deductive } \\
\text { Reasoning }\end{array}$ & Analysis & Inference & Evaluation & $\begin{array}{c}\text { Critical } \\
\text { Thinking }\end{array}$ \\
\hline $\mathrm{N}$ & 300 & 300 & 300 & 300 & 300 & 300 \\
\hline $\begin{array}{c}\text { Kolmogor- } \\
\text { ov-Smirnov Z }\end{array}$ & 1.008 & 1.123 & 1.246 & 1.249 & 1.131 & 1.168 \\
\hline $\begin{array}{c}\text { Asymp. Sig. } \\
\text { (2-tailed) }\end{array}$ & .098 & .089 & .057 & .055 & .068 & .075 \\
\hline
\end{tabular}

Table 6. the Output of Kolmogorov-Smirnov Test to Examine the Normality of the Academic Achievement Variable

\begin{tabular}{cc}
\hline & Academic Achievement(score) \\
\hline $\mathrm{N}$ & 300 \\
\hline Kolmogorov-Smirnov Z & 1.190 \\
\hline Asymp. Sig. (2-tailed) & .080 \\
\hline
\end{tabular}

Regarding the values, the significance level achieved in the critical thinking and academic achievement scales was higher than $5 \%$, therefore, the null hypothesis or the assumption of the normal distribution of samples at $5 \%$ error level was confirmed. It meant that there was no significant difference between the distribution of samples with normal distribution. According to the central limit theorem which states that when the number of samples exceeds 30 , it moves towards normality, it is concluded that the distribution of data is normal.

\section{Testing Hypotheses}

Hypothesis 1: Critical thinking and its subscales have a significant relationship with students' academic achievement of English language course.

To investigate the first hypothesis, Pearson correlation coefficient was used:

Table 7. Pearson Correlation Coefficient Between Academic Achievement and Critical Thinking

\begin{tabular}{cccccccc}
\hline $\begin{array}{c}\text { Academic } \\
\text { Achievement }\end{array}$ & Pearson Correlation & $.771^{\star \star}$ & $.770^{\star \star}$ & $.837^{\star \star}$ & $.953^{\star \star}$ & $.905^{\star \star}$ & $.933^{\star \star}$ \\
\hline Sig. (2-tailed) & .000 & .000 & .000 & .000 & .000 & .000 \\
\hline $\mathrm{N}$ & 300 & 300 & 300 & 300 & 300 & 300 \\
\hline
\end{tabular}


According to the table, correlation coefficient between academic achievement of English language course and the subscales of critical thinking, i.e. inductive reasoning, deductive reasoning, analysis, inference, and evaluation are .771, .770, .837, .953, and .905 respectively. Because these values are positive and statistically significant, therefore, academic success of English language course and the subscales of critical thinking are consistent and increasing the subscales of critical thinking, increases educational performance. Also, correlation coefficient of academic success and critical thinking variable is .933, which is positive and close to 1 and is statistically significant. In other words, with increasing critical thinking in students, their English language success increases.

Hypothesis 2: Eleventh grade female students' academic achievement of English language course is predictable based on critical thinking.

In order to investigate the second hypothesis, regression test was used:

Table 8. Regression Test for Analyzing the Effect of Critical Thinking on Academic Achievement

\begin{tabular}{|c|c|c|c|c|c|c|}
\hline \multirow[b]{2}{*}{ Model } & & \multicolumn{2}{|c|}{ Un-standardized Coefficients } & \multirow{2}{*}{$\begin{array}{c}\text { Standardized } \\
\text { Coefficients }\end{array}$} & \multirow[t]{2}{*}{$\mathrm{t}$} & \multirow[t]{2}{*}{ Sig. } \\
\hline & & $\mathrm{B}$ & Std. Error & & & \\
\hline \multirow[t]{2}{*}{1} & (Constant) & -1.294 & .389 & & -3.327 & .001 \\
\hline & $\begin{array}{l}\text { Critical } \\
\text { Thinking }\end{array}$ & .626 & .014 & .933 & 44.661 & .000 \\
\hline
\end{tabular}

Dependent Variable: score20

The results of this test showed that $\mathrm{R}$ Square, which indicates the change in the regression model in the total variation of the dependent variable is .626 for this model which indicates that $62 \%$ of the changes in English language academic achievement are due to critical thinking.

According to the software output, the standardized beta coefficient is equal to .933 and with regard to the sig value which is statistically significant at $1 \%$ level, in fact, this coefficient shows that for increasing one unit of critical thinking, students' academic achievement of English language course increases by .933 units.

Table 9. Pearson Correlation Coefficient, $R$ Square, and Durbin-Watson Statistic for Critical Thinking Variable

\begin{tabular}{cccc}
\hline Model & R Square & Std. Error of the Estimate & Durbin-Watson \\
\hline 1 & .928 & .84519 & 1.817 \\
\hline
\end{tabular}

Meanwhile, Durbin-Watson's statistics ( Table 9) in the final model which is for testing self- correlation between error sentences, is 1.817 and more than 1.5. So, the assumption of un-correlation between the error sentences is confirmed. According to the results that the model variance analysis is used to measure the validity of linear regression model with at least one independent variable, indicates that the significance level of this test in this model is 0.000 which is valid.

\section{Discussion}

In this study, the relationship between critical thinking and each of its subscales and students educational performance of English language course was investigated. Also, the predictability of English language achievement based on critical thinking was verified. The analysis of the results revealed that critical thinking and all of its subscales correlated significantly with students' educational achievement of English language course and by increasing each of them, academic achievement increased. Also, the results of regression test showed that students' academic achievement of English language course is predictable based on critical thinking.

The findings of this study are in line with that of Vierra (2014), Fong et al. (2017), and Ashoori (2014) who found a significant relationship between critical thinking and academic success. However, 


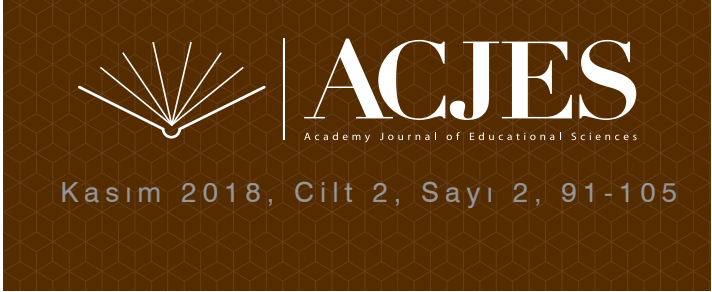

the findings contradict with that of Stupnisky, Renaud, Daniels, Haynes, and Perry (2007), Shirrel (2008), Bakhshi and Ahanchian (2013), and Doleck et al.(2017) in terms of the number of participants, the educational context, sampling method, and statistical procedures.

Today educational experts agree that critical thinking should not only be one of the goals of education, but also should be an integral part of education at any given time. Because it is a thinking type which, by analyzing, evaluating, selecting, and applying, creates the best solution in human being. That is what the world needs today (Forst, 1997; Williams \& Cole, 2018). Just having the information cannot be useful and it is important to analyze the information. Critical thinking as one of the necessities of 21 st century and one of the goals of educational systems can help students to be successful in their education and get higher scores. In explaining the finding of this research, it can be said that students with high critical thinking ability do not easily accept information from the environment, they think about them and study different perspectives on issues and at the end, take the best decision and act on it. They are able to acquire knowledge themselves. These students evaluate the various solutions and eventually choose the best one. Applying and reinforcing critical thinking allows students to increase their progress and get higher scores.

The results of this study would be beneficial for schools to guide students in educational matters. In addition, teachers would benefit from the findings of this study in a way that they would enhance their instructional strategies and help students in order to reinforce and use critical thinking style and for this purpose, pre-service and in-service teacher training programs should prepare teachers. Also, schools and education officials should support teachers' efforts in this realm. Furthermore, the findings may benefit students in such a way that they should try to enhance and use this thinking style.

The present study suffered from some limitations which were beyond the control of the researcher and, thus, would place restrictions on the conclusions of the study. In this research, the size of the participants (300 students) limited the study's generalizability. Besides, there might be some sources of intervening variables such as respondents' linguistic, social, and cultural background knowledge that would fail to control. On the other hand, since completing the critical thinking questionnaire was time-consuming and students hadn't enough time to answer the questionnaire at school, they were asked to answer them at home which led to a waste of time (due to problems such as forgetting, missing the questionnaires, and unwillingness to answer them).

\section{Conclusion}

Parametric tests with respect to being normal in the first hypothesis showed that critical thinking and its subscales have a significant and positive correlation with academic achievement of English language course. Or, in other words, with increase in the variable of critical thinking and its subscales, academic achievement increases. Also, the results of the regression test in the second hypothesis indicated that the critical thinking variable has a significant effect on educational performance of English language course. 


\section{References}

Acharya, K. P. (2017). Exploring critical thinking for secondary level students in Chemistry: From insight to practice. Journal of Advanced College of Engineering and Management, 3, 31-39

Ashoori, J. (2014). Relationship between academic achievement and self-efficacy, critical thinking, thinking styles, and emotional intelligence in nursing students. Scientific Journal of Hamadan Nursing \& Midwifery Faculty, 22(3), 15-23.

Azizi-Fini, I., Hajibagheri, A.,\& Adib- Hajibagheri, M. (2015). Critical thinking skills in nursing students: A comparison between freshmen and senior students. Nursing and Midwifery Studies, 4(1), 18-26.

Bakhshi, M.,\& Ahanchian, M. R. (2013). A proposed model to predict academic achievement: The role of critical thinking and self-regulated learning strategies. Iranian Journal of Medical Education, 13(2), 153-163

Doleck, T., Bazelais, P., Lemay, D. J., Saxena, A.,\& Basnet, R. B. (2017). Algorithmic thinking, cooperativity, creativity, critical thinking, and problem-solving: Exploring the relationship between computational thinking skills and academic performance. Journal of Computers in Education, 4(4), 355-369.

Dwyer, C. P., Hogan, M.J.,\& Stewart, I. (2014). An integrated critical thinking Framework for the 21st century. Thinking Skills and Creativity, 12, 43-52.

Evans, S. (2013). Perspectives on the use of English as a business lingua franca in Hong Kong. Journal of Business Communication, 50(3), 255-292.

Facione, P. A.,\& Facione, N. C.(1993). The California Critical Thinking Skills Test: Form A and Form B, test manual. Millbrea, CA: California Academic Press.

Facione, P. A ,\& Facione, N. C. (1997). Critical thinking assessment in nursing education programs: An aggregate data analysis. California : California Academic Press.

Facione , P. A. (2000). The disposition toward critical thinking: Its character, measurement, and relationship to critical thinking skill. Informal Logic, 20(1), 61-84.

Fong, C. J., Kim, Y., Davis, C. W., Hoang, T.,\& Kim, Y. W. (2017). A meta-analysis on critical thinking and community college student achievement. Thinking Skills and Creativity, 26, 71-83.

Forst, P.J. (1997). Building bridges between critical theory and management education. Journal of Management Education, 21, 361-370.

Fuad, N. M., Zubaidah, S., Mahanal, S.,\& Suarsini, E. (2017). Improving junior high schools' critical thinking skills based on test three different models of learning. International Journal of Instruction, 10(1), 101-116.

Gajda, A., Karwowski, M.,\& Beghetto, R. A. (2016). Creativity and academic achievement: A metaanalysis. Journal of Educational Psychology, 109(2), 269-278.

Gelardi, A. M. G.,\& Emby, C. E. N. (2005). The "shock" factor in students' performance in accounting examination. Advances in Accounting, 21, 219-231. 
Ghanizadeh, A. (2017). The interplay between reflective thinking, critical thinking, self-monitoring, and academic achievement in higher education. Higher Education, 74(1), 101-114.

Gojkov, G., Stojanovic, A.,\& Rajic, A. G. (2014). Critical thinking of students: Indicator of quality in higher education. Procedia- Social and Behavioral Sciences, 191, 591-596.

Guven, M.,\& Kurum, D. (2007). Teacher candidates' learning styles and critical disposition. Elektronik Sosyal Bilimler Dergisi, 6(21), 60-90.

Hakimi, S., Hejazi, E.,\& Gholamali Lavasani. M. (2015). A study of the relationships between cognitive styles, and personality traits with academic achievement in Tehran University students. Journal of Individual Differences, 3(6), 1-25.

Hashemi, S. A. (2011). The use of critical thinking in social science text books of high school: A field study of Fars province in Iran. International Journal of Instruction, 4(1), 63-78.

Hirish, J. B.,\& Peterson, J. B. (2008). Predicting creative and academic success with a "fake-proof" measure of the Big- Five. Journal of Research in Personality, 42(5), 1323- 1333.

Hong, K. S. (2002). Relationship between students and instructional variables with satisfaction and learning from a web-based course. The Internet and Higher Education, 5(3), 267-281.

Hong, Y. C.,\& Choi, I. (2015). Assessing reflective thinking in solving design problems: The development of a questionnaire. British Journal of Educational Technology, 46(4), 848-863.

Jahn, D.,\& Kenner, A. (2018). Critical thinking in higher education: How to foster it using digital media. In Kergel, D., Heidkamp, B., Telléus, P.K., Rachwal, T., Nowakowski, S. (Eds.), The Digital Turn in Higher Education (pp. 81-109).Springer VS, Wiesbadan.

Kahu, E. R.,\& Nelson, K. (2017). Student engagement in the educational interface: Understanding the mechanisms of student success. Higher Education Research and Development, 37(1), 58-71.

Kelly, G. J.,\& Lincona, P. (2018). Epistemic practices and science education. In Matthews, Michael R. (Ed.), History, philosophy and science teaching. (pp. 139-165). Springer, Cham.

Khalili, H.,\& Hossein Zadeh, M. (2003). Investigation of reliability, validity and normality of Persian version of the California Critical Thinking Skills Test, Form B. Journal of Medical Education, 3(1), 29-32.

Lau, J. Y. F. (2011). An introduction to critical thinking and creativity. Massachuset: John Wiley \& Sons Inc.

Li, L. (2016). Thinking skills and creativity in second language education: Where are we now? Thinking Skills and Creativity, 22, 267-272.

Magrabi, S. A. R., Pasha, M. I.,\& Pasha, M. Y. (2018). Classroom teaching to enhance critical thinking and problem-solving skills for developing IOT applications. Journal of Engineering Education Transformations, 31(3), 152-157.

Pramila, N., Bahadur, T. R.,\& Bahadur, S. J. (2018). Factors determining English test score of high school students in Rural Nepal. International Journal of Research Studies in Education, 7(3), 19-32. 
Ross, D., Leoffler, K., Schipper, S., Vandermeer, B.,\& Allan, G. M. (2013). Do scores on three commonly used measures of critical thinking correlates with academic success of health professions trainees: A systematic review and meta-analysis. Academic Medicine, 88(5), 724-734.

Seah, K. K. (2018). Immigrant educators and students' academic achievement. Labour Economics, $51,152-169$.

Sepahi, V., Khazaei, M. R., Khoshy, A., Iranfar, S.,\& Timare, M. (2014). The correlation between critical thinking disposition and academic achievement of preclinical and clinical medical students at Kermanshah University of Medical Sciences. Educational Researches of Medical Sciences, 3(1), 10-15.

Shirrel, D. (2008). Critical thinking as a predictor of success in an associate degree nursing Program. Teaching and Learning in Nursing, 3(4), 131-136.

Shoval, E., Sharir, T., Arnon, M.,\& Tenenbaum, G. (2018). The effect of integrating movement into the learning environment of kindergarten children on their academic achievements. Early Childhood Education Journal, 46(3), 355-364.

Stein, B., Haynes, A ., Redding, M., Ennis, T.,\& Cecil, M.(2007). Assessing critical thinking in STEM and beyond: In Iskander, M. (Ed.), Innovations in e-learning. Instruction Technology, Assessment, and Engineering Education (pp. 79-82). Springer, Dordrecht.

Thadphoothon, J.(2005). Promoting critical thinking in language learning through computer-mediated collaborative learning: A preliminary investigation (Doctoral Dissertation. University of Canberra, Canberra, Australia.

Topcu, S.,\& Leana-Tascilar, M. Z. (2018). The role of motivation and self-esteem in the academic achievement of Turkish gifted students. Gifted Education International, 3(1), 3-18.

Trenholm, S. (2017). Thinking through communication: An introduction to the study of human communication. Routledge.

Vierra, R. W. (2014). Critical thinking: Assessing the relationship with academic achievement and demographic factors (Doctoral Dissertation). University of Minnesota, Minnesota, USA.

Vizeshfar, F.,\& Torabizadeh, C. (2018). The effect of teaching based on dominant learning style on nursing students' academic achievement. Nurse Education in Practice, 28, 103-108.

Voskoglou, M. G.,\& Buckley. S. (2012). Problem solving and computers in a learning environment. Egyptian Computer Science Journal, 36(4), 28-46.

Williams, S.V.,\& Cole, J. M. (2018). The study in native cultural competency in mainstream schooling. Cham: Palgrave McMillan.

Willingham, D. T.(2008). Critical thinking: Why is it so hard to teach? Arts Education Policy Review, 109(4), 21-32.

Zare, H.,\& Rastegar, A. (2015). The casual model of predicting virtual education students academic achievement: The role of intelligence beliefs, achievement goals and academic emotions. Social Cognition, 3(2), 19-32.

Zhang, J.,\& Lynch, R. (2018). The relationship between primary 5and6 students' perceptions of parental encouragement and their academic achievement in Mandarin learning at an international school, Bangkok. Scholar: Human Sciences, 9(2), 243-253. 